\title{
Repressive Policy of the Soviet State against Clerisy of the National Regions in Eastern Siberia in Evaluations of Modern Historiography
}

\author{
Nadezhda A. Dankina* \\ Khakass Research Institute of Language, Literature and History \\ 23 Shchetinkin Str., Abakan, Republic of Khakassia, 655017, Russia
}

Received 04.09.2014, received in revised form 19.09.2014, accepted 21.10.2014

\begin{abstract}
Modern evaluations of the reasons for regional clerisy mass repressions and specific features of political "cleansings" in state institutions and public organizations in the 1920-s - early 1930-s are represented in the article. Historiography of "the Red Terror" aimed at clerisy of Eastern Siberia's national regions is studied separately.
\end{abstract}

Keywords: repressions, clerisy, East Siberian national regions, modern historiography.

Research area: History.

New evaluations of clerisy repressions in the national regions of Siberia were offered in the beginning of the 2000s by S. A. Papkov and S. A. Krasil'nikov. S. A. Papkov stated a problem that "original sources and research works do not provide an unambiguous answer about true motives of mass prosecution of the clerisy in national suburbs in the middle of the 1930s" (Papkov S. A, 2000). He considers that explanation of these processes should be searched for in consideration of the character of social development of these regions and formation of the localclerisy'snational consciousness peculiarities. According to S.A. Papkov, one of the causes of mass repressions was the fact that in the changing situation of the 1930s representatives of the new national clerisy had not managed "to select the correct life reference points without coming into conflict with the rapidly changing policy"(Papkov, 2000; Papkov, 2001: 24). He asserts that national clerisy's aspiration for solving management problems, problems of culture and people's life development turned subsequently to the central points of charges against national groups, "when the authorities organised judicial or extrajudicial processes against them in accordance with "counterrevolutionary nationalism" (Papkov, 2001: 23).

According to S.A. Papkov another cause of clerisy's repressions in the national regions of Siberia was that after the mass change of staff in 1934-1935 there was no full submission of local executives. Latent opposition to the spreading policy was continued by other lines of the party that earlier were considered as consecutive introducers of central and regional

(C) Siberian Federal University. All rights reserved

* Corresponding author E-mail address: nadezhda.dankina@yandex.ru 
public authorities. Obviously, such opposition arose in connection with the conducted social experiments and "cleansings" in these regions reached the degree of sharpness that became difficult tolerated (Papkov, 2001: 25).

In S.A. Papkov's opinion, any prosecutions of the Stalin's epoch, including those of national character, acted as political (or sociopolitical) repressions. Secondly, these prosecutions had dual character: on the one hand, they were a tool of mass forcing of citizens to the certain behaviour or action and, on the other hand, they served as a mean of putting down protests of separate groups of population which opposition was dangerous for the central authority's actions. According to S.A. Papkov's point of view, repressions in the national regions of Siberia in the beginning of the 1930s started as a forcing action and then resulted in retaliatory operations against the most circumspect public elements (Papkov, 2001: 20-21).

S.A. Papkov considers that the basic feature of the terror in Southern Siberia was that the national aspect of repressions was expressed in defeat of the local (national) clerisy (Papkov, 2001: 23).

Theoretical and methodological approaches of the repressive policy of the Soviet State concerning Siberian clerisy are presented in S.A. Krasil'nikov's scientific report "Sociopolitical Development of Clerisy in 1917middle 30s" (Krasil'nikov, 1995).

The complete statement of his concept was published in Historical Encyclopaedia of Siberia (Historical Encyclopaedia, 2009). Having analysed history of Siberian clerisy during revolutionary and post-revolutionary periods, S.A. Krasil'nikov comes to conclusion that "the change of political regimes and administrative bodies immediately affected clerisy and employees. Some people came to power, others lost their seats and jobs and lost their social status" (Historical Encyclopaedia, 2009: 632). He ascertains that discrimination was observed both during the red and white regimes. Circumspect people of the Kolchak's regime were subjected to repressions. And the part of them was shot. In the late 1920s practice of discrimination measures application concerning groups of experts according to their past professional and political activity was iterated (Historical Encyclopaedia, 2009: 632).

S.A. Krasil'nikov was the first of the explorers who set a problem of the political cleansing of official bodies and public organizations in the $1920 \mathrm{~s}$ - beginning of the 1930 s. He wrote that in relation to real and potential opponents the power, along with direct repressions, applied different kinds of restrictions of civil and political rights and freedoms (first of all suffrages), removal and exile by extrajudicial (administrative) procedures. The state machinery "cleansing" period was also a tool for experts' social-professional discrimination. The most significant of them was carried out in 1924. Its result was removal of 4.7 thousand people or 11 $\%$ of the employees checked by the commissions from the Siberian state machinery. Despite low qualification level of the majority of employees, 1.8 thousands of "the cleansed" on political basis highly skilled experts got absolute prohibition for work in official bodies. The number of this group increased throughout 1920 (Historical Encyclopaedia, 2009: 634). S.A. Krasil'nikov refers the second "cleansing" of the state machinery to the end of the 1920 s - beginning of the 1930s. It is connected with the Shakhty Trial in 1928. In total, in Siberian bodies of the state machinery, it affected about 15 thousand people or $16.3 \%$ from the number of employees who had undergone the checkout, first of all "former prisoners", "nonvoters" and exiled. Number of experts among them remained traditionally high (Historical Encyclopaedia, 2009). 
S.A. Krasil'nikov offered classification of those who had undergone the political cleansing. He divides the employees, subjected to dismissal from the Soviet machinery, into three categories. The first category of employees was prohibited further work in the Soviet machinery. They lost the right to severance pays, pension provisions, were excluded from trade unions and other public organisations. The second category of employees was forbidden to work in this establishment, but was permitted to have another Soviet job. The third category of employees was forbidden to hold key positions. They were demoted but could continue working in the establishment (Krasil'nikov, 1995: 28).

N.A. Dankina is one of the first who referred to the problem of political cleansing in Khakassia. S.A. Krasil'nikov's methodological approach was taken as a basis of her research. In N.A. Dankina's opinion, the first political cleansing in Khakassia took place at the end of the 1920s - beginning of the 1930s. In the beginning of 1931 the cleansing was carried out in five regions and in all establishments of regional significance, such as regional ground control, Khakass Consumers Association, City Consumers Association and Tomsk Transport Consumers Association, Local Economic Department, Regional Financial Department, Office of Public Prosecutor, Regional Administrative Office, Savings Bank, National Court, Regional Office of Communications, Department of Trade, Regional Department of National Education and major Mining Controls of "Tsvetmetzoloto" system in Saralinsk and Abakan. In total 1857 men were checked. 222 of them were cleansed" (Dankina, 2004: 83).

On the basis of S.A. Krasil'nikov's qualification, N.A. Dankina distinguished three categories of the employees who had undergone the political cleansing. In Khakassia 55 men were referred to the first category of the employees, who didn't have the right to work in the Soviet machinery, 88 men were referred to the second category, 79 men were referred to the third category of the employees with the right to occupy less responsible and technical positions. 69 men were dismissed without application of categories. In general, 353 men were subjected to official penalties (Krasil'nikov, 1995: 83-85).

Repressive policy in the national regions of Southern Siberia is studied by E.P. Mamysheva. After S.A. Krasil'nikov she sets a problem of "red terror" which provided execution of "class hostile elements, involved in counterrevolutionary plots and their isolation in concentration camps" (Mamysheva, 2011: 57). S.D. Mainagashev, the leader of national movement of Khakassia and his family, G.I. Itygin (Khakassia), G.M. Tokmashev, G.I. Gurkin, V.K. Maneyev, L.M. Edokov, I.S. Alagyzov (Oirotiya), Ya.K. Telgerekov (Gornaya Shoriya) underwent repressions. Representatives of this clerisy group were suspected of attempt to make an alliance of Oirotiya, Khakassia and Gornaya Shoriya to form an independent republic for the purpose of its separation from the USSR (Mamysheva, 2011: 181)

Also, for the first time in historiography, E.P. Mamysheva describes cases named "Oirotian embassy in Moscow", initiated on 1 January 1926 and "The Oirots, Shors and other national minorities of Siberia and the Far East", initiated on 1 January 1929. In these cases Altaians V.K. Maneyev and Yalbachev together with the chairman of Khakass district executive committee Itygin were accused of carrying out nationalist activity aimed at Turkish republic establishment (Mamysheva, 2011).

E.P. Mamysheva pays attention to the political cleansing at the end of the 1920 s - beginning of the 1930s and comes to the conclusion that the political cleansing was an integral part of the personnel policy of the All-Union Communist Party Bolsheviks. Workers' and Peasants' 
Inspection, special working teams, authorized representatives of the Soviet Party apparatus and public organizations' activity were directed at its implementation (Mamysheva, 2011). She underlines peculiarity of the political cleansings for the national regions in Siberia and notices that the cleansing of state machineries in the national regions was also used with a view of struggle against "bourgeois nationalism". In Gornaya Shoriya a campaign of "Gornaya-Shoriya case" was initiated. According to this case the secretary of the district party committee Danilov was accused of "the great Russian chauvinism" and Napazakov, Chudoyakov, Telgerekov were accused of local nationalist demonstration organization. E.P. Mamysheva also tries to distinct causes of repressions against the national clerisy, such as spontaneous consolidation of the clerisy, awakening of national consciousness, tendency to emphasize national, economic, household and other features of their own people, accentuate a region for the central authority (Mamysheva, 2011: 183).

In the middle of the 1930s, according to E.P. Mamysheva's researches, in different regions of Oirotiya different cases concerning "A.I. Arbanakov's organization" and "organizations of Manzyrov-Tabanakov" were fabricated. In 1936 the case of "Altaian nationalists' block", which was supposed to be in collusion with the similar organisations of Khakassia and Gornaya Shoriya, was fabricated. Many leaders of this organisation were declared as agents of Japanese Secret Intelligence Service (Mamysheva, 2011: 189).

In the last years it is much written about activity of the counterrevolutionary nationalist organization "Siberian Turkomen's Union". S.V. Karlov was one of the first who referred to this theme at the end of the 1990 s - beginning of the 2000s. However, his monograph research "Mass Repressions in 1930 (as exemplified in
Khakassia)" was published only in 2011. He writes that in 1934 the Special Board of the Western-Siberian Regional Court in the closed judicial session considered a case of the so-called counterrevolutionary nationalist organisation in Western Siberian region "Siberian Turkomen's Union". 37 people were brought to court regarding this case. All of them were accused of the fact that for the purpose of an independent bourgeoisdemocratic Turkic republic establishment in the territory of Khakassia, Gornaya Shoriya and Oirotiya with joining Tana, the Tuvinian republic created the counterrevolutionary nationalist organisation "Siberian Turkomen's Union", prepared a program and Charter of this organisation and had actively been involved in anti-Soviet activity (Krasil'nikov, 1995: 119-121).

Stages of the counterrevolutionary nationalist movement in the south of Siberia were distinguished in accordance with the accusation:

- The first stage (1923-1931) was characterised by legal and semilegal activity of the bourgeois-nationalist clerisy which did not share the party's policy concerning ethnic issues. Nationalists of Khakassia and Oirotiya propagated an idea about the Turkic republic among young promising national workers. The centre of this counterrevolutionary activity was in Moscow, where among students of Communist University of the Toilers of the East, the Oirots, Shors and Khakass there was an association of fellow-countrymen. There at closed meetings issues concerning the Turkic autonomous republic establishment were discussed;

- The second stage (1932 - the first half of 1933) was characterised by formation of counterrevolutionary nationalist personnel of Khakassia into an illegal organization, named "Siberian Turkomen's Union". It was also characterized by the fact that the head of organisation K.A. Maitakov transferred organizational activity on knocking together cells 
of organisation in Gornaya-Shor national region of Western Siberia, into the cities of Leningrad and Irkutsk. In that period the organisation did not have direct aims for rebel yet;

- The third stage (the middle of 1933 spring of 1934) was characterised by the change of orientation program. In the course of the accusation it was told that the purpose of the counterrevolutionary organization already was "establishment of a bourgeois-democratic state in the territory, invaded by eastern people in Western Siberia, by an armed revolt against the Soviet State". The armed revolt "was planned at the moment of Japanese intervention beginning and existence of the Turkic republic was expected under Japanese protectorate" (Krasil'nikov, 1995: 125-126).

S.V. Karlov gives evaluation of "Siberian Turkomen's Union" case in the context of modern evaluations of political repressions in the first half of the 1930s. "Political repressions of the first half of the 1930s in many respects surpassed any possible threat of the Soviet State in Khakassia. After all, overwhelming majority of those, who underwent repressions for political reasons, did not make any counterrevolutionary actions. They only to some extent expressed disagreement with the policy of the All-Union Communist Party Bolsheviks and the Soviet government" (Krasil'nikov, 1995: 128).

S.A. Papkov was also engaged in the study of "Siberian Turkomen's union". He refers January-February of 1934 to the initial phase of the national clerisy's prosecutions in the national regions of Siberia (Papkov, 2000).

The last research, devoted to this subject, was made by E.P. Mamysheva. She notices that activity of the union didn't have purpose to overthrow the government. The case of "Siberian Turkomen's Union" did not become the unique act of revealing and punishment of the bourgeois counter-revolutionaries nationalists. After the landmark case, persecutions of the national clerisy continued with renewed vigour (Mamysheva, 2011: 188).

Since 1920 in Yakutia, similar to "Siberian Turkomen's Union", there was an organisation named «Yakut Labour Union of Federalists» which put forward declaration of Yakutia state sovereignty as its primary goal. N.N. Dyakonova and A.N. Dyachkova write about this organisation and its leaders fates (Dyakonova N.N., 2002; Dyachkova A.N., 2008). The latter notices that ethnographer-specialist in folklore G.V. Ksenofontov's family was subjected to repression with regard to the case of Yakut Labour Union of Federalists. A.N. Dyachkova exemplified by a separate person's fate, identified features of the repressive policy in Yakutia. As well as P.A. Oiunsky, G.V. Ksenofontov was condemned for participation in the subversive organization's work. Its activity was directed on separation of the Yakut Republic in favour of Japan, where Ksenofontov was assigned a part of a spy (Dyachkova, 2008: 122-123).

Modern national historiography has given new evaluations of mass political repressions and quantity of clerisy subjected to repressions in the late 1930. AccordingtoN.A.Dankina'scalculations in Khakassia in the process of mass repressions, 318 people, who represented mental potential, suffered. In 1937-1938 78 representatives of the national clerisy were subjected to repressions (Dankina, 2004: 98). According to E.P. Antonov's estimation, from 1920 till the beginning of 1950 about 500 Yakuts, representatives of the clerisy underwent repressions (Historical Encyclopaedia, 2009: 638). S.V. Baldano studies Buryat clerisy and mentions that outstanding representatives of the national Buryat clerisy, such as Ts. Zh. Zhamtsarano, B.B. Baradiin, E.-D. Rinchino, S. Shirabon, P. Damdinov, I. Dampilon, D. Ardin et al, were subjected to repressions and later shot (Historical Encyclopaedia, 2009: 640). 
It is necessary to notice that there is still no data in the scientific literature about the quantity of the subjected to repression clerisy in Gornaya Shoriya and Oirotiya. This issue remains topical for studying.

S.V. Karlov stated the following evaluation of the mass political repressions in Khakassia. He considers that the administrative board of the region greatly suffered from terror. Instead of the party and Soviet and economic leaders, who were subjected to repressions on the basis of framedup cases, there came workers promoted by Stalin. Their characteristic feature was humility to the people's will. Change of personnel started to have mass repressions nature (Karlov, 2011: 160). As for repressions of the Tuvinian clerisy, researchers notice that many political processes in the Tuvinian National Republic were developing substantially under the influence of the Soviet Union. V.A. Ushkalov writes that "with some delay the wave of repressions came from Moscow to the Sayan ridge. Yesterday's confederates, building the new Tuva, suffered the same fate as the builders of the new Russia" (Ushkalov, 2001: 27).

Modern evaluation of repressions in Tuva is of current interest. R. Sh. Kharunov writes the following about it. Repressions in the Tuvinian National Republic affected, first of all, the managerial personnel and reflected the struggle of the "new Pro-Soviet" political elite against the "old statesmen" (Kharunov, 2009: 126). In 1929 Mongush Buyan-Badyrgy, a hereditary noyon of
Daa-kozhuun, an outstanding man of state and politics, one of the founders of the Tuva state was arrested on suspicion of counterrevolutionary activity. In 1932 he was shot. In October 1938 the chairman of the Council of Ministers of the TNR SatChurmit-Dazhi, the chairman of Presidium of Little Khural of TNR AdygTyulyushKhemchik-ool, the chairman of the board of Tuvinian bank OyunDanchai, the state prosecutor Kara-Sal Pirinlei, the minister of trade and industry SatLopsan, plenipotentiary of the TNR in the MNR KuularSungar-ool and deputy state prosecutor OyunSengiizhik were shot (Kharunov, 2009: 125). As R. Sh. Kharunov specifies, repressions scales against other groups of the clerisy such as teachers, doctors, writers and men of art were much less. Thereby, bases for progressive development of the national culture were preserved. Such conclusion was made by M. M.-B. Kharunova in her monograph "Sociopolitical Development of Tuva in the Middle of the $20^{\text {th }}$ Century" (Kharunova, 2011).

Thus, new evaluations of repressions concerning clerisy of the national regions of Southern Siberia raised problems of the causes for mass repressions of the national clerisy, "red terror", political cleansings of the 1920s beginning of the 1930s, analysis of the clerisy's mass repressions, the total number of clerisy subjected to repression, etc. Unfortunately, the majority of issues within the limits of the designated theme demand further studying and new evaluations.

\section{References}

1. Dankina N.A. The Clerisy of Khakassia at the end of the 30 s of the $19^{\text {th }}-20^{\text {th }}$ Centuries. Abakan, 2004.

2. Papkov S.A. Repressive Policy of the Soviet State in Siberia, June 1928, 1941: Dissertation of Dr. of Historical Sciences. Novosibirsk, 2000.

3. Dyakonova N.N. The Yakut Clerisy in National History: Destinies and Time (the end of the $19^{\text {th }}$ Century - 1917). Novosibirsk, 2002.

4. Dyachkova A.N. G.V. Ksenofontov: Scientist, Politician, Lawyer. Yakutsk, 2008. 
5. Historical Encyclopaedia of Siberia. Novosibirsk, 2009.

6. Karlov S.V. Mass Repressions in 1930 (based on materials of Khakassia). Abakan, 2011.

7. Krasil'nikov S.A. Sociopolitical Development of the Clerisy in 1917- mid 30s: Dissertation in the Form of Scientific Report for Dr. of Historical Sciences. Novosibirsk, 1995.

8. Mamysheva E.P. National-State Building in Southern Siberia in 1917-1941: History, Experience, Problems. Abakan, 2011.

9. Ushkalov V.A. Features of Political Repressions in Tuva // Political Repressions in Khakassia and in Other Regions of Siberia (1920-1950). Materials of the Interregional scientific and practical conference. Abakan, 2001.

10. Kharunov R. Sh. Formation of Clerisy in the Tuvinian National Republic (1921-1944). Abakan, 2009.

11. Kharunova M. M.-B. Sociopolitical Development of Tuva in the Middle of the $20^{\text {th }}$ Century. Novosibirsk, 2011.

\section{Репрессивная политика Советского государства против творческой интеллигенции \\ в национальных регионах Восточной Сибири \\ в оценках современной историографии}

Н.А. Данькина

Хакасский научно-исследовательский институт языка, литературы и истории Россия, 655017, Республика Хакасия, Абакан, ул. Щетинкина, 23

В статье представлены современные оценки причин массовых репрессий региональной интеллигенции и особенностей политических «чисток» государственных учреждений и общественных организаций в 1920 - начале 1930-х г2. Отдельно рассматривается историография «красного террора» в отношении интеллигенции национальных регионов Восточной Сибири.

Ключевые слова: репрессии, творческая интеллигенция, Восточно-Сибирские начиональные регионы, современная историография.

Научная спещиальность: 07.00.00 - исторические науки. 